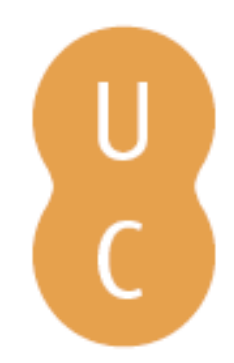

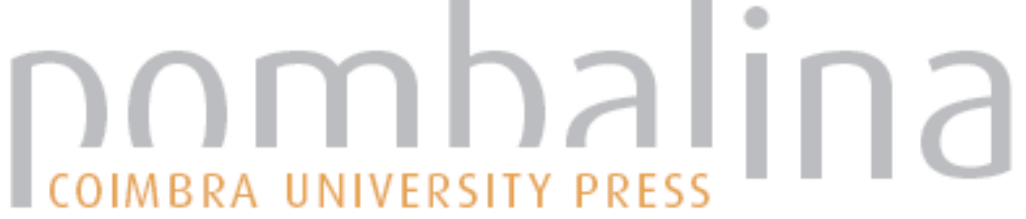

\section{Drivers of wildland fire behaviour variation across the Earth}

Fernandes, Paulo M.; Sil, Ângelo; Ascoli, Davide; Cruz, Miguel G.;
Autor(es): Alexander, Martin E.; Rossa, Carlos G.; Baeza, Jaime; Burrows, Neil; Davies, G. Matt; Fidelis, Alessandra; Gould, James S.; Govender, Navashni; Kilinc, Musa; McCaw, Lachlan

Publicado por: Imprensa da Universidade de Coimbra

URL persistente:

URI:http://hdl.handle.net/10316.2/44671

DOI:

DOI:https://doi.org/10.14195/978-989-26-16-506_154

Accessed : $\quad$ 26-Apr-2023 02:50:46

A navegação consulta e descarregamento dos títulos inseridos nas Bibliotecas Digitais UC Digitalis, UC Pombalina e UC Impactum, pressupõem a aceitação plena e sem reservas dos Termos e Condições de Uso destas Bibliotecas Digitais, disponíveis em https://digitalis.uc.pt/pt-pt/termos.

Conforme exposto nos referidos Termos e Condições de Uso, o descarregamento de títulos de acesso restrito requer uma licença válida de autorização devendo o utilizador aceder ao(s) documento(s) a partir de um endereço de IP da instituição detentora da supramencionada licença.

Ao utilizador é apenas permitido o descarregamento para uso pessoal, pelo que o emprego do(s) título(s) descarregado(s) para outro fim, designadamente comercial, carece de autorização do respetivo autor ou editor da obra.

Na medida em que todas as obras da UC Digitalis se encontram protegidas pelo Código do Direito de Autor e Direitos Conexos e demais legislação aplicável, toda a cópia, parcial ou total, deste documento, nos casos em que é legalmente admitida, deverá conter ou fazer-se acompanhar por este aviso.
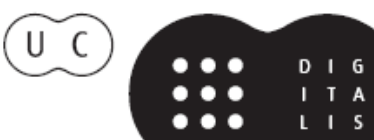


\section{ADVANCES IN}

\section{FOREST FIRE RESEARCH}

\section{8}

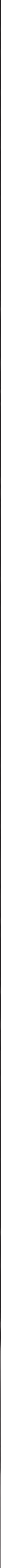


Short contribution - Fire Management

\section{Drivers of wildland fire behaviour variation across the Earth}

Paulo M. Fernandes ${ }^{1 *}$; Ângelo Sil ${ }^{1}$; Davide Ascoli ${ }^{2}$; Miguel G. Cruz ${ }^{3}$; Martin E. Alexander ${ }^{4}$; Carlos G. Rossa $^{1}$; Jaime Baeza ${ }^{5}$; Neil Burrows ${ }^{6}$; G. Matt Davies ${ }^{7}$; Alessandra Fidelis ${ }^{8}$; James S. Gould ${ }^{3}$; Navashni Govender ${ }^{9}$; Musa Kilinc ${ }^{10}$; Lachlan $\mathrm{McCaw}^{11}$.

${ }^{1}$ Centro de Investigação e Tecnologias Agroambientais e Biológicas, Universidade de Trás-os-Montes e Alto Douro. Quinta de Prados, 5001-801 Vila Real (Portugal), \{pfern@utad.pt*\}

${ }^{2}$ Dipartimento di Agraria, University of Naples Federico II. Via Università 100, 80055 Portici, Napoli (Italy), \{davide.ascoli@unina.it\}

${ }^{3}$ CSIRO. GPO Box 1700, Canberra, ACT 2601 (Australia) \{miguel.cruz@csiro.au\}

${ }^{4}$ Wild Rose Fire Behaviour. 180 - 50434 Range Road 232, Leduc County, AB T4X OL1 (Canada), \{mea2@telus.net\}

${ }^{5}$ Universidad de Alicante.Ap. 99, E- 03080,Alicante (Spain) \{jaime.baeza@ua.es\}

${ }^{6}$ Department of Parks and Wildlife. 17 Dick Perry Avenue, Kensington WA 6151 (Australia),

\{neil.burrows@dpaw.wa.gov.au\}

${ }^{7}$ School of Environmental and Natural Resources, The Ohio State University. Columbus, Ohio, USA

\{davies.411@osu.edu\}

${ }^{8}$ Universidade Estadual Paulista (UNESP), Instituto de Biociências. Av. 24A, 1515, 13506-900, Rio Claro, Brazil, http://orcid.org/0000-0001-9545-2285 \{afidelis@rc.unesp.br\}

${ }^{9}$ Conservation Management, Kruger National Park. Private Bag X402, Skukuza 1350, South Africa, \{navashni.govender@sanparks.org\}

${ }^{10}$ Country Fire Authority, F\&EM - Predictive Services. 8 Lakeside Drive East Burwood VIC 3151 (Australia), \{m.kilinc@cfa.vic.gov.au\}

${ }^{11}$ Science and Conservation, Dpt. Biodiversity, Conservation and Attractions. Locked Bag 2, Manjimup WA 6258 (Australia), \{lachie.mccaw@dbca.wa.gov.au\}

\footnotetext{
Abstract

Fire behaviour characteristics define the impacts on society and the environment. While wildland fire science has expanded to include the analysis of fire activity and effects across the globe, an understanding of global fire behaviour patterns and its drivers remains incomplete. We utilized the literature and unpublished datasets as sources for compiling a worldwide fire environment and fire behaviour database consisting of field-based experimental fires, planned-ignition prescribed fires and wildfires. Analysis of the database allows for the assessing of the influences of fuel and weather descriptors on fire behaviour characteristics at various scales, namely climate zone, biome, ecoregion, and vegetation type. The database comprises nearly 6000 fires. Fire spread rate and fireline intensity vary by five orders of magnitude (seven in the former case if smouldering is considered). Variation in fire-spread rate is dominated by fuel moisture content within Koppen-Geiger climates, except in tropical wet and hot desert climates, where wind speed prevails. Fuel structure is less important than weather-related variables, but it explains 35 and $30 \%$ of the variability within monsoon-influenced humid subtropical and hot summer Mediterranean climates, respectively. Fuel structure and load metrics increase in importance in regards to fireline intensity, being the dominant influence (66$91 \%$ ) in hot semi-arid, temperate oceanic, and hot summer Mediterranean climates. Fuel moisture content exerts by far the major control in the variation in fire spread rate within broad vegetation types (forest, woodland, shrubland, grassland), while fuel structure metrics dominate the variation observed in fireline intensity, except in woodlands, where fuel moisture content is slightly more influential. Efforts to understand potential fire activity and fire regime shifts in relation to global change, and the formulation of policies for adaptive fire management will benefit from the results of this study.
}

Keywords: fire spread rate, fireline intensity, fire modelling, fuel structure, fire weather, fire environment 


\section{Introduction}

The environmental and societal consequences of wildland fire depend on how fast it spreads, its areal extent, how much biomass it consumes, and how much and at what rate it releases energy. While wildland fire science has expanded to include the analysis of fire activity and effects across the globe (Moritz et al. 2012), an understanding of global fire behaviour patterns and their drivers remains incomplete, and is addressed by the on-going BONFIRE project.

We utilized the literature and unpublished datasets as sources for compiling a worldwide fire environment and fire behaviour database consisting of field-based experimental fires, planned-ignition prescribed fires and wildfires. Among other possibilities, analysis of the database allows for assessing the influences of fuel and weather descriptors on fire behaviour characteristics at various spatial scales, namely climate type and different levels of vegetation classification. In this study we quantify the relative importance of fuel and weather-related variables in determining fire behaviour variation at those scales.

\section{Data and Methods}

We surveyed the peer-reviewed and grey literature and identified candidate field-based experimental fires to include in the database, supplemented by unpublished data on file. We compiled information from natural or activity (slash and masticated) fuels, the former comprising both flaming and smoldering fires. Fires backing into the wind or downslope, as well as ignition patterns resulting in fire front interaction in both experimental and prescribed fires (e.g. strip-head firing) were not included in the analysis, as well as fires spreading as fronts $<2 \mathrm{~m}$ wide that do not reach their potential rate of spread even under mild weather conditions (Wotton et al. 1999). When multiple observation periods were available, wildfire data collection was limited to the period of maximum rate of spread in a given vegetation type. We retrieved as much information as possible on:

- Fire weather: wind speed, ambient temperature and relative humidity, fuel moisture contents per condition - dead or live - and size class, Canadian Forest Fire Weather Index System codes and indices (Van Wagner 1987);

- terrain slope;

- surface fuel properties and other attributes of the fuel complex (e.g. loads per size class and live or dead condition, curing or \% fine dead fuel, fuel depth or height, fuel layer cover), fuel type (defined by the existing surface fuel layer(s), e.g. litter-grass);

- type of ignition source (i.e. point or line), and ignition line length;

- characteristics of the heading fire, i.e. the forward section of the fire front: rate of spread, flame geometry, and fireline intensity (Byram 1959);

- fuel consumption by fuel layer and size class.

The resulting database is, understandably, highly heterogeneous in its completeness. Each fire was assigned a georeferenced location, Koppen-Geiger climate classification (Peel et al. 2007), mean annual temperature and rainfall (1970-2000) from the WorldClim 2 database (Fick and Hijmans 2017), biome and ecoregion (Olson et al. 2001), NCAR LSM surface type (e.g. cool broadleaved deciduous forest) (Bonan 1996), generic vegetation type (i.e. forest, woodland, shrubland, or grassland), and dominant species. Additionally we attributed reliability scores for weather, fuel and fire behaviour characteristics (Cheney et al. 2012).

Regression tree analysis of fire spread rate and fireline intensity as a function of fuel and weather variables was carried out after adjusting rate of spread for zero slope (Sullivan et al. 2014). The results are presented after discarding the influence of ignition type and ignition line length. 


\section{Preliminary Results and Conclusion}

The database comprises about 6000 fires (experimental fires $-73 \%, 15 \%$ wildfires, and 12\% prescribed burns) from 33 countries. However, $72 \%$ of the data comes from Australia, USA, Canada, and South Africa (Figure 1), reflecting their long-standing research programs and fire management policies. Proportionally, forest is the more represented vegetation type, followed by grassland, woodland, and shrubland.

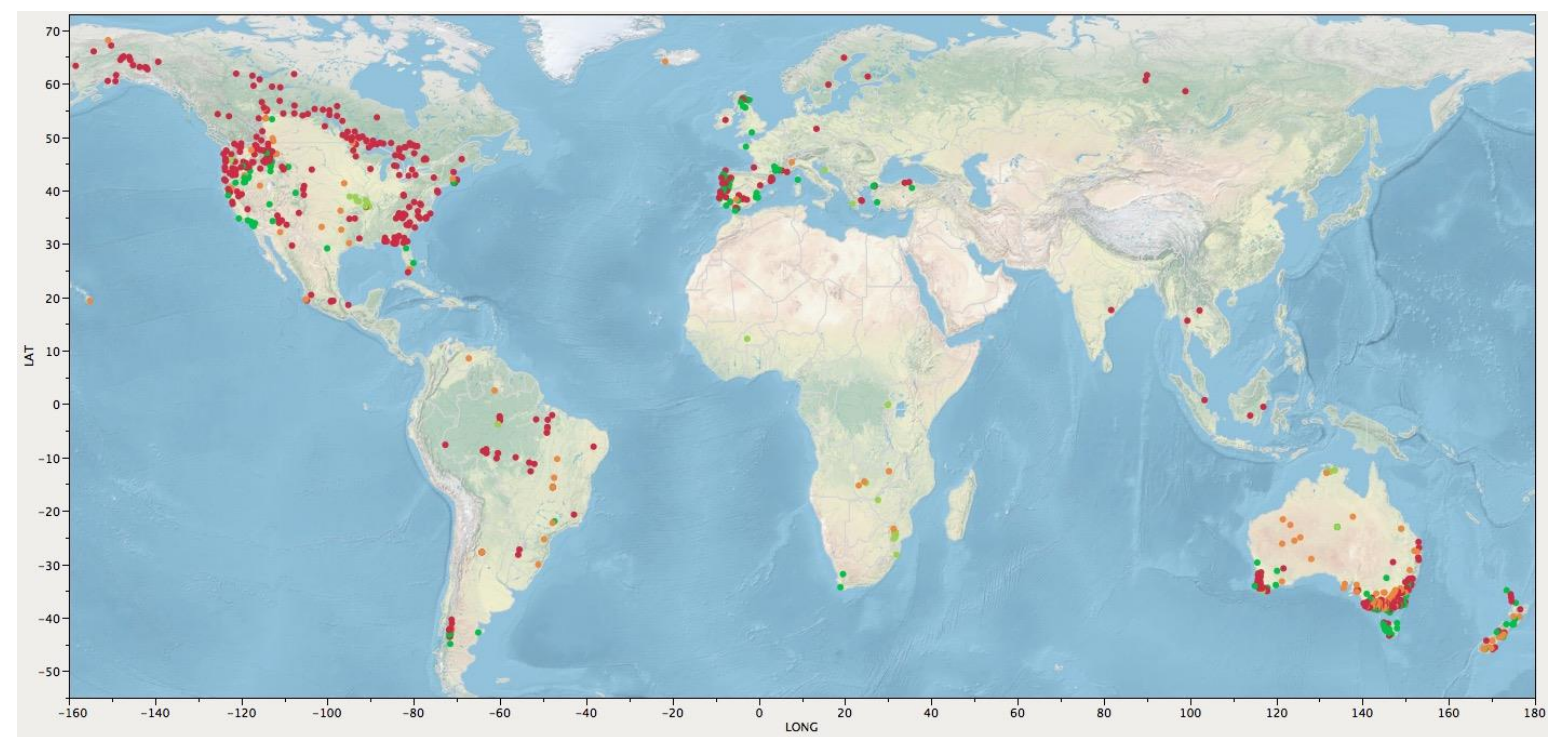

Figure 1 - Location of the fires in the database. Red = forest; orange = grassland; light green = woodland; green = shrubland. Sites in North America, temperate Australasia, and southwestern Europe are prevalent, with scarce locations in Russia, Asia and the other regions of Africa and, to a lesser degree, Central America and South America.

Fire spread rate and fireline intensity in the database vary by five orders of magnitude, and by seven in the former case if smouldering is considered. Variation in fire-spread rate is dominated by fuel moisture content within Koppen-Geiger climates, except in tropical wet and hot desert climates, where wind speed prevails. Fuel structure is less important than weather-related variables, but it explains 35 and $30 \%$ of the variability within monsoon-influenced humid subtropical and hot summer Mediterranean climates, respectively. Fuel structure and load metrics increase in importance with regards to fireline intensity, being the dominant influence (66-91\%) in hot semi-arid, temperate oceanic, and hot summer Mediterranean climates. Fuel moisture content exerts by far the greatest control on variation in fire spread rate within a given broad vegetation type (forest, woodland, shrubland, grassland), while fuel structure metrics dominate the variation observed in fireline intensity, except in woodlands, where fuel moisture content is slightly more influential.

Efforts to understand potential fire activity and fire regime shifts in relation to global change, and the formulation of policies for adaptive fire management will benefit from the results of this study. Visit https://www.researchgate.net/project/BONFIRE-gloBal-scale-analysis-and-mOdelliNg-ofFIRE-behaviour-potential-PTDC-AAG-MAA-2656-2014 to keep up with the latest project developments.

\section{Acknowledgments}

This study was funded by the Foundation for Science and Technology (FCT) and co-financed by the European Regional Development Fund (ERDF) through COMPETE 2020 - Operational Program for Competitiveness and Internationalization (POCI), in the frame of the BONFIRE project - gloBalscale analysis and mOdelliNg of FIRE behavior potential (PTDC/AAG-MAA/2656/2014). 


\section{References}

Bonan GB (1996) A land surface model (LSM version 1.0) for ecological, hydrological, and atmospheric studies: Technical description and user's guide. National Centre for Atmospheric Research, Technical Note NCAR/TN-417+STR. (Boulder, CO)

Byram GM (1959) Combustion of forest fuels. In 'Forest fire: control and use'. (Ed KP Davis) pp. 6189. (McGraw-Hill: New York, NY)

Cheney NP, Gould JS, McCaw WL, Anderson WR (2012) Predicting fire behaviour in dry eucalypt forest in southern Australia. Forest Ecology and Management 280, 120-131.

Fick SE, Hijmans RJ (2017) WorldClim 2: new 1-km spatial resolution climate surfaces for global land areas. International Journal of Climatology 37: 4302-4315.

Moritz MA, Parisien MA, Batllori E, Krawchuk MA, Van Dorn J, Ganz DJ, Hayhoe K (2012) Climate change and disruptions to global fire activity. Ecosphere 3, art49, doi:10.1890/ES11-00345.1

Olson DM, Dinerstein E, Wikramanayake ED, Burgess ND, Powell GVN, Underwood EC, D’Amico JA, Itoua I, Strand HE, Morrison JC, Loucks CJ, Allnutt TF, Ricketts TH, Kura Y, Lamoreux JF, Wettengel WW, Hedao P, Kassem KR (2001) Terrestrial ecoregions of the world: a new map of life on Earth: a new global map of terrestrial ecoregions provides an innovative tool for conserving biodiversity. BioScience 51, 933-938.

Peel MC, Finlayson BL, McMahon TA (2007) Updated world map of the Köppen-Geiger climate classification. Hydrology and Earth System Sciences Discussions 4, 439-473.

Sullivan AL, Sharples JJ, Matthews S, Plucinski MP (2014) A downslope fire spread correction factor based on landscape-scale fire behaviour. Environmental Modelling and Software 62, 153-163.

Van Wagner CE (1987) Development and structure of the Canadian Forest Fire Weather Index System. Government of Canada, Canadian Forestry Service For. Tech. Rep. 35. (Ottawa, ON)

Wotton BM, McAlpine RS, Hobbs MW (1999) The effect of fire front width on surface fire behaviour. International Journal of Wildland Fire 9, 247-253. 